\title{
INFLUENCE OF BIOPREPARATION RHYZOHUMIN AND PLANT GROWTH REGULATOR BIOGLOBINE ON SYMBIOTIC NITROGEN-FIXING SYSTEM AND YIELD OF SOYBEAN
}

\author{
O. M. Murach ${ }^{1}$, V. V. Volkohon ${ }^{2}$ \\ ${ }^{1}$ Institute of Agriculture of Northern East, NAAS \\ Zelena Str., Sad, Sumy region, 42343, Ukraine; e-mail: agronauka@gmail.com \\ ${ }^{2}$ Institute of Agricultural Microbiology and Agroindustrial Manufacture, NAAS \\ 97, Shevchenka str., Chernihiv, 14027, Ukraine; e-mail: volkogon@ukr.net
}

The paper presents the results of study on the influence of pre-sowing treatment of soybean seeds with the microbial preparation Rhyzohumin and growth regulator Bioglobine, and their separate application (Rhyzohumin was used for seeds bacterization while growth regulator was applied foliar during different phases of plants organogenesis) on the formation and functioning of a symbiotic nitrogen-fixing apparatus in the conditions of the north-eastern forest-steppe of Ukraine. Separate application of studied preparations has intensively stimulated the formation and activity of soybean-rhizobial symbiosis, compared to their joint application. Considering their stage-bystage application the preparations has a positive action and increase the grain yield of soybeans.

Key words: soybean, bacterization, Rhyzohumin, plant growth regulator Bioglobine, soybeanrhizobial symbiosis, yield.

One of the important issues in modern crop production is the development and implementation of environmentally adapted technologies for agriculture crops. Their main peculiarity is to help plants maximally adapt to environmental conditions to maximize the genetic capabilities of modern varieties and highly heterozygous hybrids. However, the variability of weather conditions in different years requires constant correction of the conditions for the development of plants through the application of particular agrotechnical means. In addition, it is well known that the effect of the same agrotechnical technique in different weather conditions can provide not only the same effect, and even have a different direction of action. It should also be noted that it is not always possible to withstand all components of different cultivating technology in agricultural production. In connection with this, there is a need for the use of certain agrotechnical techniques that would compensate to the greatest extent the possible crop losses, caused by a changes in the previous agrotechnical technique or the terms of their implementation.
Considering the ability of soybean plants to form a symbiosis with nodular bacteria and thus to improve nitrogen nutrition conditions, many studies have been conducted in recent years focusing on the effectiveness of the use of bacterial preparations. According to long-term data, soybean yield under the use of microbial preparations can grow by $25-30 \%$, and protein content in grain by $2-6 \%[1 ; 2]$.

Scientific data also claim the significant prospects for soybean seeds treatments with growth regulators, which contributes to a significant increase in the crop productivity at low cost. However, the information on the possibility of combining pre-sowing bacterization with the use of growth regulators is quite controversial.

In this regard, the purpose of our work was to study the effectiveness of the use of plant growth regulator alone and in combination with the bacterial preparation in the cultivation of soybean under the conditions of the northeastern forest-steppe of Ukraine.

Materials and methods. The study was conducted during 2016-2017 in the field conditions in the Institute of Agriculture of the North- 
East of the NAAS on a typical, low-humus, slightly leached, large-peal-medium-loamy chernozem on loess, the arable layer of which is characterized by the following main parameters: humus content $-4.1 \%, \mathrm{pH}_{\text {sal. }}-6.3$, the amount of absorbed bases is $31 \mathrm{mg}-\mathrm{Eq}$, content of the mobile forms of phosphorus is $11.3 \mathrm{mg} /$ $/ 100 \mathrm{~g}$, exchangeable potassium is $9.2 \mathrm{mg} /$ / $100 \mathrm{~g}$, content of easily hydrolyzed nitrogen by Cornfield - $11.2 \mathrm{mg} / 100 \mathrm{~g}$ of soil.

The preparations efficacy was studied on Siverka soybean variety.

The scheme of two-factor experiments included 16 variants (see the tables below), repeated four times. Variants in the repetition were placed systematically. The total area of the site in the experiment was $137 \mathrm{~m}^{2}$, accounting area $-67.2 \mathrm{~m}^{2}$. The cultivating technology of the experiment was similar to the generally accepted in given soil-climatic zone with winter wheat pre-crop. Tillage, seeding, crop maintenance and harvesting were carried out according to zonal recommendations. Soybean seeding rate was 850 thousand similar seeds per 1 hectare, seeded with ordinary row width $15 \mathrm{~cm}$. Soybean seeds were treated with Maxim XL $035 \mathrm{FS}$ (1 L/ton) 14 days before sowing and with microbial preparation and plant growth regulator at the day of seeding according to the experimental scheme following the manufacturer's recommendations [3]. For pre-sowing seed inoculation a biological preparation of complex action Rhyzohumin (TU U 24.1-00497360-003: 2007) on the basis of Bradyrhizobium japonicum M-8 was used at a rate of $2 \mathrm{~kg} /$ ton of seed. In addition to pre-sowing bacterization, seeds were treated with a solution of plant growth regulator Bioglobine (developed by Medbiocom Ukraine) - 1,000 $\mathrm{mL} / \mathrm{t}$ of seed and foliar $-1,000 \mathrm{~mL} / \mathrm{ha}$ according to the scheme of experiment. Biometric studies and accounting for soybeans were conducted according to generally accepted methods [4]. The effectiveness of legume-rhizobial symbiosis was estimated at the flowering and pod filling stage counting the number, weight and nitrogenase activity of the nodules per plant. The number and weight of nodules on the roots of plants were determined after washing out the soil-plant monoliths [5], activity of symbiotic nitrogen fixation was measured using the acetylene method [6]. The statistical data analysis of the obtained results was carried out in accordance with the existing methods [4] and the use of the software package Statistica 6.0.

Results and discussion. The conducted studies indicate that the seeds treatment with the focus preparations improves the conditions for the formation of nitrogen-fixing nodules on the roots. Their number in the flowering stage in variants with microbial preparation, alone and in combination with the growth regulator, were significantly higher (1.1-1.2-fold) compared to control data in 2016 (Table 1).

2017 data show in general the low numbers of root nodules compared to the previous year, caused by the arid weather conditions $(62 \%$ of the average multi-year rainfall value during the vegetation period, HTF - 0.7). Plant growth regulator, used for seed treatment, contributed more to the formation of nodules. A significant increase in the parameters was also obtained under the use of microbial preparation. Combined, the use of Rhyzohumin and growth regulator Bioglobine for seed treatment has no significant increase in the number of nodules.

The study of the nodule activity in the pod filling phase showed the increase of the number of nodules in the studied plants, with both microbial preparation and growth regulator contributed to the increase in the parameters compared with the control variant. Thus, in the phase of pod filling, the number of nodules increased 1.3-1.4-fold (2016) and 1.3-1.8-fold (2017), depending on the experimental variants comparing to the previous period (the flowering phase).

Significant influence of separate use of plant growth regulator for seed treatment on the formation of symbiotic apparatus of soybeans was noted in 2016. Thus the number of nodules exceeded the absolute control parameters 1.7fold (102.8 versus 61.3 units per plant).

Under the 2017 conditions, the maximum increase of the number of nodules (10.9 units/ /plant versus 19.8 units/plant in absolute control) was observed during the pod filling phase in the experimental variants with seed bacterization.

The optimal conditions for the formation of nodules under the influence of both studied factors were different depending upon the year of study. Thus, under the foliar use of the growth regulator on soybeans during the phase of budding and pod filling on the background of seed treatment with a microbial preparation in com- 
Table 1. The influence of microbial preparation Rhyzohumin and growth regulator Bioglobine under the different methods of their application on the formation of nitrogen-fixing nodules

\begin{tabular}{|c|c|c|c|c|c|}
\hline \multirow{3}{*}{$\begin{array}{c}\text { Seed } \\
\text { processing } \\
\text { (factor A) }\end{array}$} & \multirow{3}{*}{$\begin{array}{c}\text { Plant processing with Bio- } \\
\text { globine solution by } \\
\text { vegetation (factor B) }\end{array}$} & \multicolumn{4}{|c|}{ Number of nodules, U/plant } \\
\hline & & \multicolumn{2}{|c|}{2016} & \multicolumn{2}{|c|}{2017} \\
\hline & & $\begin{array}{c}\text { flowering } \\
\text { stage }\end{array}$ & $\begin{array}{c}\text { pod filling } \\
\text { stage }\end{array}$ & $\begin{array}{c}\text { flowering } \\
\text { stage }\end{array}$ & $\begin{array}{c}\text { pod filling } \\
\text { stage }\end{array}$ \\
\hline \multirow{4}{*}{ Control } & no treatment & 62.9 & 61.3 & 11.3 & 19.8 \\
\hline & budding stage & 66.8 & 80.7 & 17.2 & 19.4 \\
\hline & grain filling stage & 64.9 & 85.6 & 16.7 & 21.8 \\
\hline & $\begin{array}{l}\text { budding stage }+ \text { grain filling } \\
\text { stage }\end{array}$ & 65.0 & 90.6 & 17.9 & 22.2 \\
\hline \multirow{4}{*}{ Rhyzohumin } & no treatment & 69.4 & 90.9 & 19.0 & 30.7 \\
\hline & budding stage & 78.1 & 98.9 & 17.9 & 28.9 \\
\hline & grain filling stage & 80.2 & 95.1 & 17.3 & 24.7 \\
\hline & $\begin{array}{l}\text { budding stage }+ \text { grain filling } \\
\text { stage }\end{array}$ & 86.1 & 106.3 & 19.7 & 25.7 \\
\hline \multirow{4}{*}{ Bioglobine } & no treatment & 63.2 & 102.8 & 23.3 & 26.6 \\
\hline & budding stage & 70.8 & 112.4 & 21.7 & 28.1 \\
\hline & grain filling stage & 65.8 & 113.2 & 21.3 & 25.7 \\
\hline & $\begin{array}{l}\text { budding stage }+ \text { grain filling } \\
\text { stage }\end{array}$ & 73.0 & 138.8 & 17.7 & 31.4 \\
\hline \multirow{4}{*}{$\begin{array}{l}\text { Rhyzohumin }+ \\
\text { Bioglobine }\end{array}$} & no treatment & 77.9 & 91.1 & 15.2 & 25.0 \\
\hline & budding stage & 89.8 & 101.2 & 15.6 & 22.2 \\
\hline & grain filling stage & 79.0 & 121.9 & 16.6 & 30.3 \\
\hline & $\begin{array}{l}\text { budding stage }+ \text { grain filling } \\
\text { stage }\end{array}$ & 97.7 & 123.6 & 17.4 & 24.7 \\
\hline & $\begin{array}{ll}\text { LSD }_{05} \text { for factor } \mathrm{A} \\
\mathrm{LSD}_{05 \text { for factor } \mathrm{B}}\end{array}$ & $\begin{array}{l}5.1 \\
6.1\end{array}$ & $\begin{array}{l}13.7 \\
11.2\end{array}$ & $\begin{array}{l}5.3 \\
1.3\end{array}$ & $\begin{array}{l}6.1 \\
5.5\end{array}$ \\
\hline
\end{tabular}

bination with the growth regulator, the largest number of nodules (123.6 units per plant) was obtained, which was more than 2.0-fold higher compared with the values of absolute control and 1.4-fold higher in comparison with the similar treatment of plants in the control variant in 2017, the maximum values for this parameter (31.4 units/plant versus 19.8 units/plant in absolute control) were obtained at the background of pre-sowing treatment of the seeds by the growth regulator with subsequent plant-foliar treatments with the same preparation in two phases of organogenesis of plants.

An important criterion for the interaction of plants and bacteria is the mass of nodules on the roots of legumes. Upon the investigation of peculiarities of the formation of a soybean nitrogen-fixing apparatus, it was established that the nodulation process was active in all variants, including control, where the nodules were formed due to the presence of aboriginal rhizobia in the soil. However, not all variants of the experiment had a positive correlation between the number and weight of the nodules (Table 2).

It was established that prior to the pod filling stage the weight of nodules has increased differently. Thus, at flowering stage the roots of single soybean plant has accumulated, on average, from 0.22 to $0.44 \mathrm{mg}$ (2016) and from 0.05 to $0.15 \mathrm{mg}$ (2017) of nodules, while during pod filling stage, this figure increased 1.6-1.9-fold (2016) and 2.3-3.2-fold depending on the experimental variant in 2017 (Table 2).

It should be noted that the studied preparations influenced the formation of modules in different ways. In particular, the variant with pre-sowing seeds treatment with a complex of preparations was characterized by a greater nodular activity, while the nodules, due to such treatment, were smaller and had a lower weight compared with similar parameters of the variant with the seeds inoculation with Rhyzohumin. A similar feature was noted when comparing variants of seed treatment with a growth regu- 
Table 2. The influence of microbial preparation Rhyzohumin and growth regulator Bioglobine under the different methods of their application on the dry weight of nodules

\begin{tabular}{|c|c|c|c|c|c|}
\hline \multirow{3}{*}{$\begin{array}{c}\text { Seed } \\
\text { processing } \\
\text { (factor A) }\end{array}$} & \multirow{3}{*}{$\begin{array}{l}\text { Plant processing with Bio- } \\
\text { globine solution by } \\
\text { vegetation (factor B) }\end{array}$} & \multicolumn{4}{|c|}{ Weight of dry nodules per one plant, mg } \\
\hline & & \multicolumn{2}{|c|}{2016} & \multicolumn{2}{|c|}{2017} \\
\hline & & $\begin{array}{c}\text { flowering } \\
\text { stage }\end{array}$ & $\begin{array}{l}\text { pod filling } \\
\text { stage }\end{array}$ & $\begin{array}{c}\text { flowering } \\
\text { stage }\end{array}$ & $\begin{array}{c}\text { pod filling } \\
\text { stage }\end{array}$ \\
\hline \multirow{4}{*}{ Control } & no treatment & 0.22 & 0.43 & 0.09 & 0.16 \\
\hline & budding stage & 0.26 & 0.41 & 0.10 & 0.20 \\
\hline & grain filling stage & 0.24 & 0.47 & 0.12 & 0.17 \\
\hline & $\begin{array}{l}\text { budding stage }+ \text { grain filling } \\
\text { stage }\end{array}$ & 0.25 & 0.49 & 0.13 & 0.18 \\
\hline \multirow{4}{*}{ Rhyzohumin } & no treatment & 0.33 & 0.50 & 0.13 & 0.28 \\
\hline & budding stage & 0.41 & 0.58 & 0.12 & 0.26 \\
\hline & grain filling stage & 0.38 & 0.59 & 0.13 & 0.35 \\
\hline & $\begin{array}{l}\text { budding stage }+ \text { grain filling } \\
\text { stage }\end{array}$ & 0.44 & 0.71 & 0.15 & 0.29 \\
\hline \multirow{4}{*}{ Bioglobine } & no treatment & 0.25 & 0.48 & 0.10 & 0.23 \\
\hline & budding stage & 0.30 & 0.68 & 0.13 & 0.28 \\
\hline & grain filling stage & 0.32 & 0.67 & 0.06 & 0.31 \\
\hline & $\begin{array}{l}\text { budding stage }+ \text { grain filling } \\
\text { stage }\end{array}$ & 0.34 & 0.66 & 0.05 & 0.35 \\
\hline \multirow{4}{*}{$\begin{array}{c}\text { Rhyzohumin }+ \\
\text { Bioglobine }\end{array}$} & no treatment & 0.29 & 0.40 & 0.08 & 0.22 \\
\hline & budding stage & 0.36 & 0.48 & 0.13 & 0.21 \\
\hline & grain filling stage & 0.29 & 0.50 & 0.10 & 0.30 \\
\hline & $\begin{array}{l}\text { budding stage }+ \text { grain filling } \\
\text { stage }\end{array}$ & 0.39 & 0.54 & 0.11 & 0.26 \\
\hline & $\begin{array}{r}\mathrm{LSD}_{05} \text { for factor } \mathrm{A} \\
\mathrm{LSD}_{05 \text { for factor } \mathrm{B}}\end{array}$ & $\begin{array}{l}0.08 \\
0.09\end{array}$ & $\begin{array}{l}0.05 \\
0.08\end{array}$ & $\begin{array}{l}0.03 \\
0.02\end{array}$ & $\begin{array}{l}0.09 \\
0.06\end{array}$ \\
\hline
\end{tabular}

lator and bacterization.

The most efficient symbiotic system was formed by plants, inoculated with $B$. japonicum - the weight of nodules during flowering and pod filling stages was 1.2- and 1.5-fold higher, respectively, than control parameter (2016) (see Tables 1 and 2). The results of 2017 studies showed the same pattern. That is, for the use of bacterial inoculum, the weight of nodules was also the highest and increased 1.4- and 1.8fold relatively to the stage of development, compared with the control variant.

Biological nitrogen fixation is an effective ecological, energy-saving mean to increase nitrogen reserves in soils [9]. In this regard, it is important to have an understanding of the intensity of nitrogen fixation process and ways to enhance it.

In our experiments the nitrogen-fixing activity of the studied symbiotic systems varied over the years (Table 3 ).

Plants in the control variant formed sym- biotic system due to aboriginal rhizobia present in the soil, however their nitrogen-fixing activity was low.

All investigated preparations enhanced nitrogenase activity compared to the control variants. However, during the flowering and pod filling stages soybean ontogenesis, the growth of nitrogen-fixation activity was observed mainly due to the use of Rhyzohumin. Pre-sowing seed treatment by the growth regulator significantly influenced this parameter only in 2017 with the transition of plants to the pod filling stage.

It should be noted that the combined use of Rhyzohumin and Bioglobine for seeds treatment did not stimulated the nitrogen fixation activity, which was lower compared to the separate use of studied preparations. This feature was observed during all studied stages in both years.

It should be noted that in 2016, the level of nitrogenase activity of the nodules reached the maximum during the flowering stage, decreas- 
Table 3. The influence of microbial preparation Rhyzohumin and growth regulator Bioglobine under the different methods of their application on the nitrogenase activity of soybean root nodules

\begin{tabular}{|c|c|c|c|c|c|}
\hline \multirow{3}{*}{$\begin{array}{l}\text { Seed } \\
\text { processing } \\
\text { (factor A) }\end{array}$} & \multirow{3}{*}{$\begin{array}{l}\text { Plant processing with Bio- } \\
\text { globine solution by } \\
\text { vegetation (factor B) }\end{array}$} & \multicolumn{4}{|c|}{ Nitrogenase activity, $\mathrm{nmol} \mathrm{C}_{2} \mathrm{H}_{4}$ / plant per hour } \\
\hline & & \multicolumn{2}{|c|}{2016} & \multicolumn{2}{|c|}{2017} \\
\hline & & $\begin{array}{c}\text { flowering } \\
\text { stage }\end{array}$ & $\begin{array}{c}\text { pod filling } \\
\text { stage }\end{array}$ & $\begin{array}{c}\text { flowering } \\
\text { stage }\end{array}$ & $\begin{array}{c}\text { pod filling } \\
\text { stage }\end{array}$ \\
\hline \multirow{4}{*}{ Control } & no treatment & 423 & 142 & 225 & 210 \\
\hline & budding stage & 496 & 371 & 323 & 254 \\
\hline & grain filling stage & 442 & 398 & 247 & 218 \\
\hline & $\begin{array}{l}\begin{array}{l}\text { budding stage + grain filling } \\
\text { stage }\end{array} \\
\end{array}$ & 490 & 402 & 306 & 159 \\
\hline \multirow{4}{*}{ Rhyzohumin } & no treatment & 822 & 543 & 440 & 467 \\
\hline & budding stage & 1,010 & 658 & 460 & 689 \\
\hline & grain filling stage & 882 & 812 & 420 & 689 \\
\hline & $\begin{array}{l}\text { budding stage }+ \text { grain filling } \\
\text { stage }\end{array}$ & 970 & 829 & 555 & 963 \\
\hline \multirow{4}{*}{ Bioglobine } & no treatment & 677 & 413 & 367 & 579 \\
\hline & budding stage & 785 & 438 & 420 & 694 \\
\hline & grain filling stage & 687 & 460 & 345 & 631 \\
\hline & $\begin{array}{l}\text { budding stage + grain filling } \\
\text { stage }\end{array}$ & 812 & 552 & 755 & 858 \\
\hline \multirow{4}{*}{$\begin{array}{c}\text { Rhyzohumin }+ \\
\text { Bioglobine }\end{array}$} & no treatment & 514 & 313 & 259 & 342 \\
\hline & budding stage & 682 & 339 & 345 & 362 \\
\hline & grain filling stage & 491 & 401 & 315 & 464 \\
\hline & $\begin{array}{l}\text { budding stage + grain filling } \\
\text { stage }\end{array}$ & 639 & 592 & 328 & 444 \\
\hline & $\begin{array}{l}\mathrm{LSD}_{05} \text { for factor } \mathrm{A} \\
\mathrm{LSD}_{05 \text { for factor } \mathrm{B}}\end{array}$ & $\begin{array}{c}118 \\
87\end{array}$ & $\begin{array}{l}266 \\
255\end{array}$ & $\begin{array}{l}52 \\
88\end{array}$ & $\begin{array}{l}169 \\
174\end{array}$ \\
\hline
\end{tabular}

ing with the onset of pod filling stage. However, in the variant, where the microbial preparation was used for seed treatment, nitrogen-fixing activity was the highest and at the same time more than 3.8-fold higher compared with the absolute control parameter. The effects of both investigated factors on nitrogen-fixing activity were achieved under the seeds treatment with Rhyzohumin, followed by foliar application of Bioglobine during budding and pod filling stages (this parameter exceeded the value in the control variant with a similar treatment of plants by the growth regulator 2.1-fold.

The exploration of the dynamics of symbiotic nitrogen fixation in 2017 indicates a significant increase in the activity of fixation of atmospheric nitrogen during the pod filling stage. The exception was the parameters of absolute control, as well as controls, where a growth regulator was additionally applied in different stages of soybeans development.
Significant growth of the nitrogen fixation activity (+449 nmol $\mathrm{C}_{2} \mathrm{H}_{4}$ / plant per hour) during the flowering stage was observed in the variant with the plants treatment with the growth regulator during the budding stage on the background of pre-sowing seeds treatment with the same preparation compared to $306 \mathrm{nmol} \mathrm{C}_{2} \mathrm{H}_{4}$ / / plant per hour in a control variant with a similar treatment of plants.

The maximum values of nitrogen fixation activity in pod filling stage were observed in the variant with foliar application of growth regulator in both stages on the background of Rhyzohumin used for seed treatment, where its growth in comparison with the similar treatment of control plants (159 $\mathrm{nmol} \mathrm{C}_{2} \mathrm{H}_{4} /$ plant per hour) was 6.1 fold.

As a result of the conducted study, it was established that the soybeans yield was formed depending on the weather conditions during the years of study and application methods of plant 
growth regulator and microbial preparation use. Thus, the conditions in 2016 were more favourable for the soybean production, as evidenced by the average yield $-2.47 \mathrm{t} / \mathrm{ha}$ (Table 4 ).

Pre-sowing seed treatment with microbial preparation used for optimization of nitrogen nutrition of plants is an effective agrotechnical technique used in modern agriculture. Overall, inoculation of soybean seeds increased the yield of grain by $0.21 \mathrm{t} / \mathrm{ha}(9.1 \%)$ compared to $2.30 \mathrm{t} / \mathrm{ha}$ in absolute control.

Due to unfavourable weather conditions in 2017, soybean yield was relatively low (an average of $2.28 \mathrm{t} / \mathrm{ha}$ ). However, even under these conditions, the significant effect of separate application of inoculation and growth regulator for pre-sowing seed treatment on the formation of the crop was noted. The yield from these treatments was at a similar level of $2.29 \mathrm{t} / \mathrm{ha}$, which is $0.24 \mathrm{t} / \mathrm{ha}(11.7 \%)$ higher compared to an absolute control.

By estimating the average yield of soybeans for two years, a clear (by $10.1 \%$ ) yields increase compared to the control in the variant using Rhyzohumin was noted. The use of the growth regulator for seed treatment increased this parameter by $9.2 \%$, while the simultaneous use of both preparations - by $5.6 \%$.

According to individual studies $[9 ; 10]$, more tangible effects of growth regulators were detected under their use as seeds treatment simultaneously with microbial preparations during the vegetation period. Our study contradicts this statement. Separately, by the years of study and on average, the simultaneous pre-sowing seeds treatment with Rhyzohumin and plant growth regulator was less efficient in terms of yield formation. At the same time, foliar application of growth regulator during the budding and pod filling stages at the background of seed treatment with Rhyzohumin, resulted in $0.32 \mathrm{t} / \mathrm{ha}$ $(14.7 \%)$ yield increase relatively to absolute control $(2.18 \mathrm{t} / \mathrm{ha})$. We explain the reduction of the studied parameters under the combined soybean seeds inoculation with both preparations compared with their effectiveness when applied

Table 4. The influence of microbial preparation Rhyzohumin and growth regulator Bioglobine under the different methods of their application on the soybean yield of Siverka variety

\begin{tabular}{|c|c|c|c|c|c|c|}
\hline \multirow{2}{*}{$\begin{array}{l}\text { Seed pro- } \\
\text { cessing (factor } \\
\text { A) }\end{array}$} & \multirow{2}{*}{$\begin{array}{l}\text { Plant processing with } \\
\text { Bioglobine solution by } \\
\text { vegetation (factor B) }\end{array}$} & \multicolumn{3}{|c|}{ Yield, t/ha } & \multicolumn{2}{|c|}{ Increment, $\mathrm{t} / \mathrm{ha}$} \\
\hline & & 2016 & 2017 & mean & \pm by factor $\mathrm{A}$ & \pm by factor $B$ \\
\hline \multirow{4}{*}{ Control } & no treatment & 2.30 & 2.05 & 2.18 & K & $\mathrm{K}$ \\
\hline & budding stage & 2.32 & 2.14 & 2.23 & & 0.06 \\
\hline & grain filling stage & 2.36 & 2.26 & 2.31 & & 0.14 \\
\hline & $\begin{array}{l}\text { budding stage }+ \text { grain } \\
\text { filling stage }\end{array}$ & 2.40 & 2.30 & 2.35 & & 0.18 \\
\hline \multirow{4}{*}{ Rhyzohumin } & no treatment & 2.51 & 2.29 & 2.40 & 0.23 & $\mathrm{~K}$ \\
\hline & budding stage & 2.55 & 2.35 & 2.45 & & 0.05 \\
\hline & grain filling stage & 2.57 & 2.36 & 2.47 & & 0.06 \\
\hline & $\begin{array}{l}\text { budding stage }+ \text { grain } \\
\text { filling stage }\end{array}$ & 2.62 & 2.38 & 2.50 & & 0.10 \\
\hline \multirow{4}{*}{ Bioglobine } & no treatment & 2.47 & 2.29 & 2.38 & 0.21 & $\mathrm{~K}$ \\
\hline & budding stage & 2.50 & 2.32 & 2.41 & & 0.03 \\
\hline & grain filling stage & 2.55 & 2.35 & 2.45 & & 0.07 \\
\hline & $\begin{array}{l}\text { budding stage + grain } \\
\text { filling stage }\end{array}$ & 2.51 & 2.34 & 2.43 & & 0.04 \\
\hline \multirow{4}{*}{$\begin{array}{c}\text { Rhyzohumin }+ \\
\text { Bioglobine }\end{array}$} & no treatment & 2.41 & 2.21 & 2.31 & 0.14 & $\mathrm{~K}$ \\
\hline & budding stage & 2.43 & 2.29 & 2.36 & & 0.05 \\
\hline & grain filling stage & 2.47 & 2.32 & 2.40 & & 0.09 \\
\hline & $\begin{array}{l}\text { budding stage + grain } \\
\text { filling stage }\end{array}$ & 2.48 & 2.32 & 2.40 & & 0.09 \\
\hline & $\begin{array}{l}\mathrm{LSD}_{05} \text { for factor } \mathrm{A} \\
\mathrm{LSD}_{05 \text { for factor } \mathrm{B}}\end{array}$ & $\begin{array}{l}0.15 \\
0.07\end{array}$ & $\begin{array}{l}0.18 \\
0.05\end{array}$ & & & \\
\hline
\end{tabular}


separately with the possible overdose of physiologically active substances. At separate use of preparations - pre-sowing seeds bacterization with Rhyzohumin and foliar application of Bioglobine, such overdose does not occur, as the growth regulator is influencing not the seed or seedling, but enhance the already formed legume-rhizobial nitrogen fixation system.

Consequently, the stage-by-stage application of the studied factors: a microbial preparation as a seed treatment and a growth regulator as a foliar treatment of vegetative plants during the budding and pod filling stages has contributed the most to the increase of the productivity of the symbiotic soybean-rhizobial system and crop yield, while the combined seeds treatment with Rhyzohumin and plant growth regulator Bioglobine was shown to be the least effective for the studied parameters.

1. Капушев А. У. Эффективность нитрагинизации семян сои / А. У. Капушев, Б. Ф. Садыков // Масличные культуры. — 1992. — № 6. C. $19-20$.

2. Турін Є. М. Специфічність взаємодії сортів сої з різними штамами бульбочкових бактерій / Є. М. Турін, Ф. Ф. Адамень // Вісник аграрної науки. - № 11. - 2005. - С. 82-84.

\section{ВПЛИВ БІОПРЕПАРАТУ РИЗОГУМІНУ ТА РЕГУЛЯТОРА РОСТУ РОСЛИН БІОГЛОБІНУ НА СИМБІОТИЧНУ АЗОТФІКСУВАЛЬНУ СИСТЕМУ І ПРОДУКТИВНІСТЬ СОЇ}

\author{
О. М. Мурач ${ }^{1}$, В. В. Волкогон ${ }^{2}$ \\ ${ }^{1}$ Інститут сільського господарства Північного \\ Сходу НААН, с. Сад, Сумський район, \\ Сумська область \\ ${ }^{2}$ Інститут сільськогосподарської мікробіології \\ та агропромислового виробництва НААН, \\ м. Чернігів
}

Наведено результати досліджень впливу передпосівної обробки насіння сої мікробним препаратом Ризогуміном та регулятором росту Біоглобіном, а також поетапного їх застосування (Ризогумін для бактеризаиії насіння, а рістстимулятор - по листу у
3. Мікробні препарати у землеробстві. Теорія і практика : монографія / [В. В. Волкогон, О. В. Надкернична, Т. М. Ковалевська та ін.] ; за ред. В. В. Волкогона. - К. : Аграрна наука, 2006. - $312 \mathrm{c}$.

4. Доспехов Б. А. Методика полевого опыта с основами статистической обработки результатов исследований / Б. А. Доспехов. - М. : Агропромиздат, 1985 . $-351 \mathrm{c.}$

5. Посыпанов Г. С. Методы изучения биологической фиксации азота воздуха : Справочное пособие / Посыпанов Г. С. - Москва : Агропромиздат, 1991. - $300 \mathrm{c}$.

6. The acetylene-ethylene assay for $\mathrm{N}_{2}$-fixation: Laboratory and field evaluation / R. W. F. Hardy, R. D. Holsten, E. K. Jackson, R. C. Burns // Plant Physiol. - 1968. - Vol. 43, № 8. - P. 1185-1207.

7. Продуктивність окремих сільськогосподарських культур за застосування регуляторів росту рослин / Л. С. Сремов, А. В. Сидоренко, Р. В. Олефір, С. О. Агафонова // Вісник Полтавської аграрної академії. - 2009. - № 1. C. 43-45.

8. Іщенко В. А. Ефективність використання Ризогуміну і Поліміксобактерину у поєднанні 3 мікродобривом та регулятором росту при вирощуванні гороху вусатого типу в Північному Степу / В. А. Іщенко // Сільськогосподарська мікробіологія. - 2013. - Вип. 17. - С. 89-100.

9. Мишустин Е. Н. Биологическая фиксация атмосферного азота / Е. Н. Мишустин, В. К. Шильникова. - М. : Наука, 1968. - 531 с.

\section{ВЛИЯНИЕ БИОПРЕПАРАТА РИЗОГУМИНА И РЕГУЛЯТОРА РОСТА РАСТЕНИЙ БИОГЛОБИНА НА СИМБИОТИЧЕСКУЮ АЗОТФИКСИРУЮЩУЮ СИСТЕМУ И ПРОДУКТИВНОСТЬ СОИ}

\author{
О. Н. Мурач ${ }^{1}$, В. В. Волкогон ${ }^{2}$ \\ ${ }^{1}$ Институт сельского хозяйства \\ Северо-Востока НААН, с. Сад, Сумской р-н, \\ Сумская обл. \\ ${ }^{2}$ Институт сельскохозяйственной микробиологии \\ и агропромышленного производства НААН, \\ г. Чернигов
}

Приведень результаты исследований влияния предпосевной обработки семян сои микробнымм препаратом Ризогумином и регулятором роста Биоглобином, а также поэтапного их применения (Ризогумин для бактеризации семян, а ростстимулятор - 
різні фази органогенезу рослин) на формування $i$ функиіонування симбіотичного азотфіксувального апарату в умовах північносхідного Лісостепу України. Окреме застосування для передпосівної обробки насіння мікробного препарату та Біоглобіну інтенсивніше стимулює формування $і$ активність соєво-ризобіального симбіозу, ніж використання препаратів у комплексі. Препарати сприяють підвищенню зернової продуктивності сої за умови їх поетапного застосування.

Ключові слова: соя, бактеризаиія, Ризогумін, регулятор росту рослин Біоглобін, соєво-ризобіальний симбіоз, урожайність. по листу в различные фазы органогенеза растений) на формирование и функиионирование симбиотического азотфиксирующего аппарата в условиях северо-восточной Лесостепи Украины. Раздельное применение для предпосевной обработки семян микробного препарата и Биоглобина более интенсивно стимулирует формирование и активность соево-ризобиального симбиоза, чем использование препаратов в комплексе. Препараты способствуют увеличению зерновой продуктивности сои при поэтапном их применении.

Ключевые слова: соя, бактеризация, $\mathrm{Pu-}$ зогумин, регулятор роста растений Биоглобин, соево-ризобиальный симбиоз, урожайность. 